経 営史学

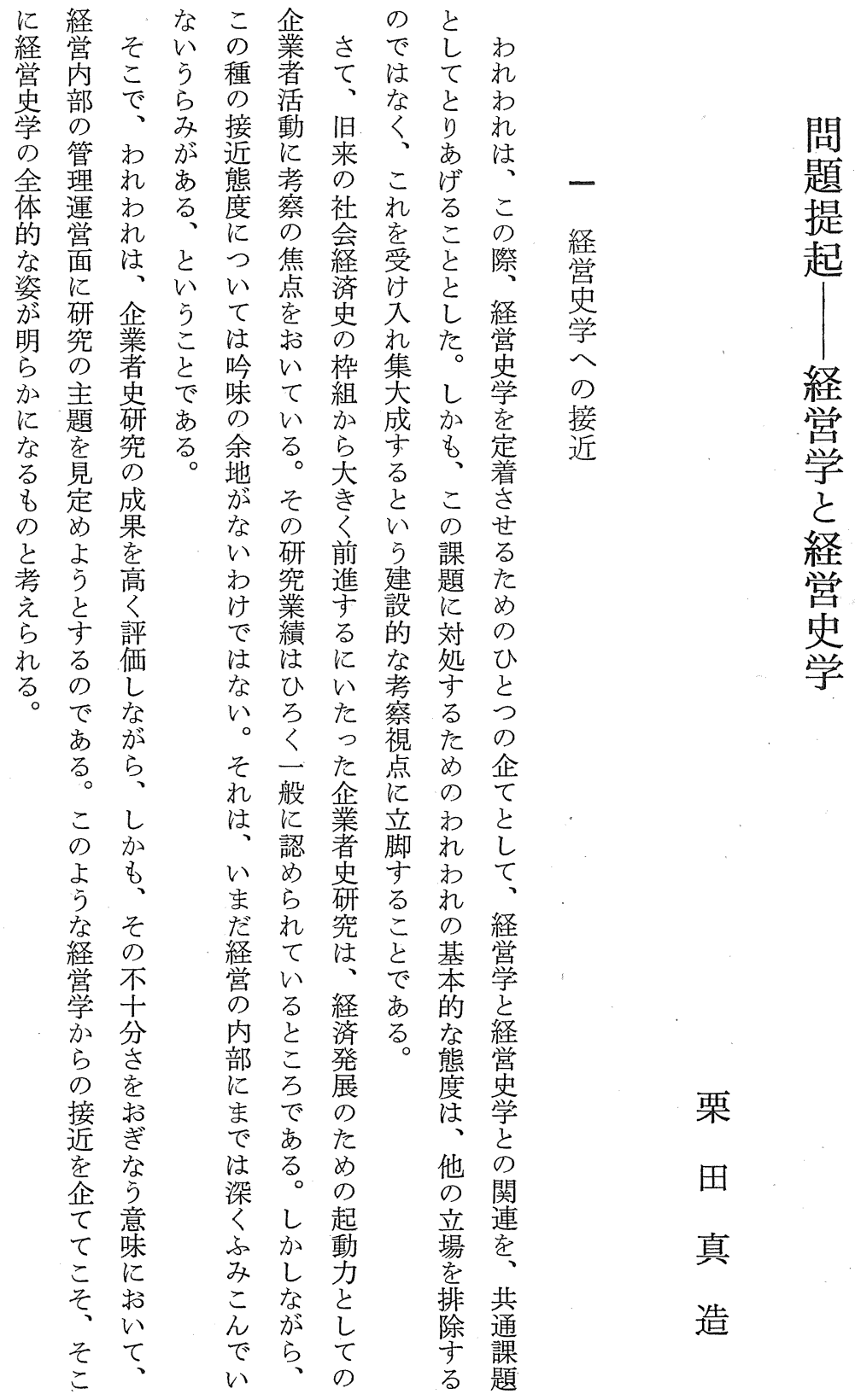


第 9 巻 第 1 号

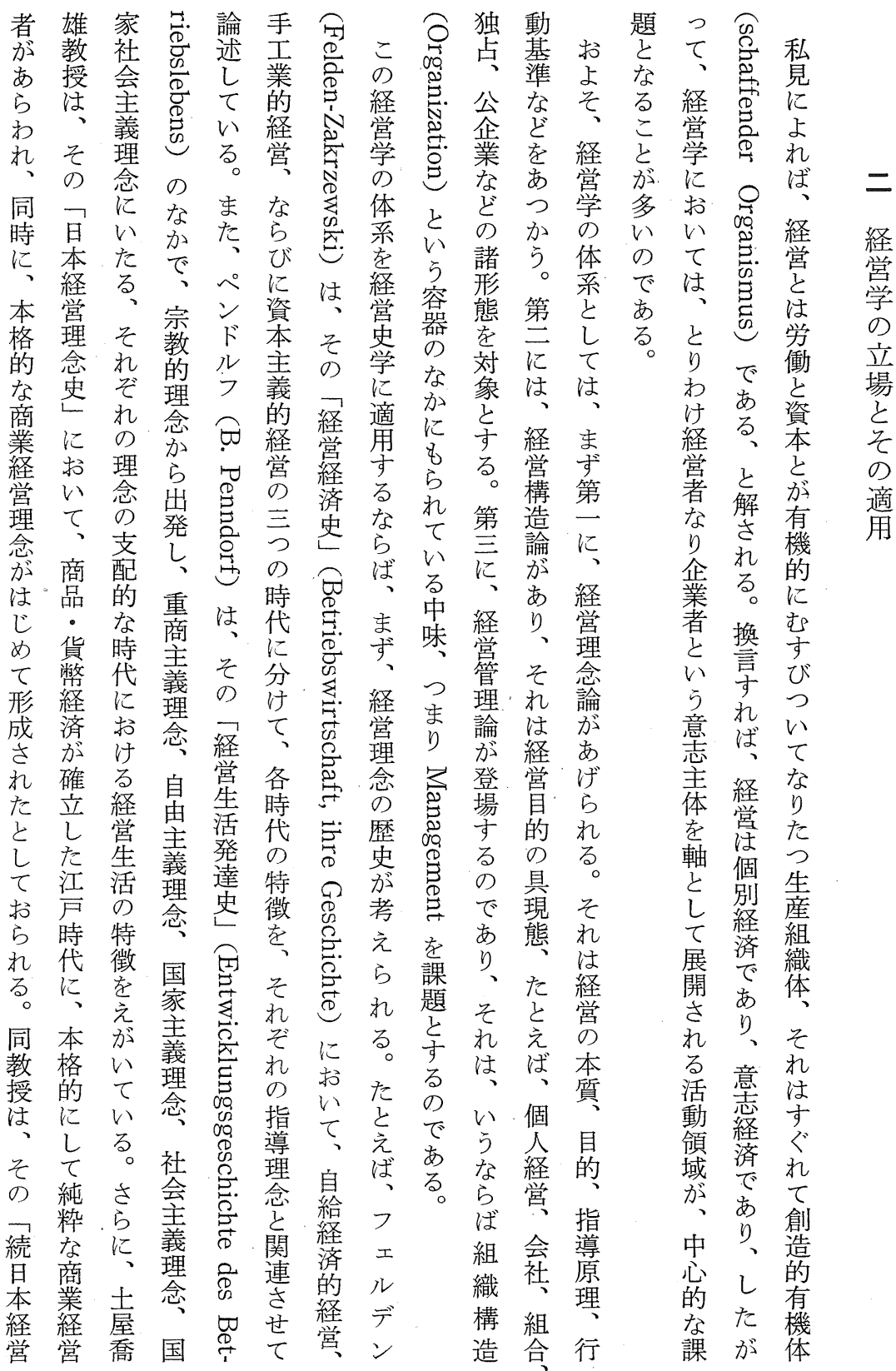


経営, 史学

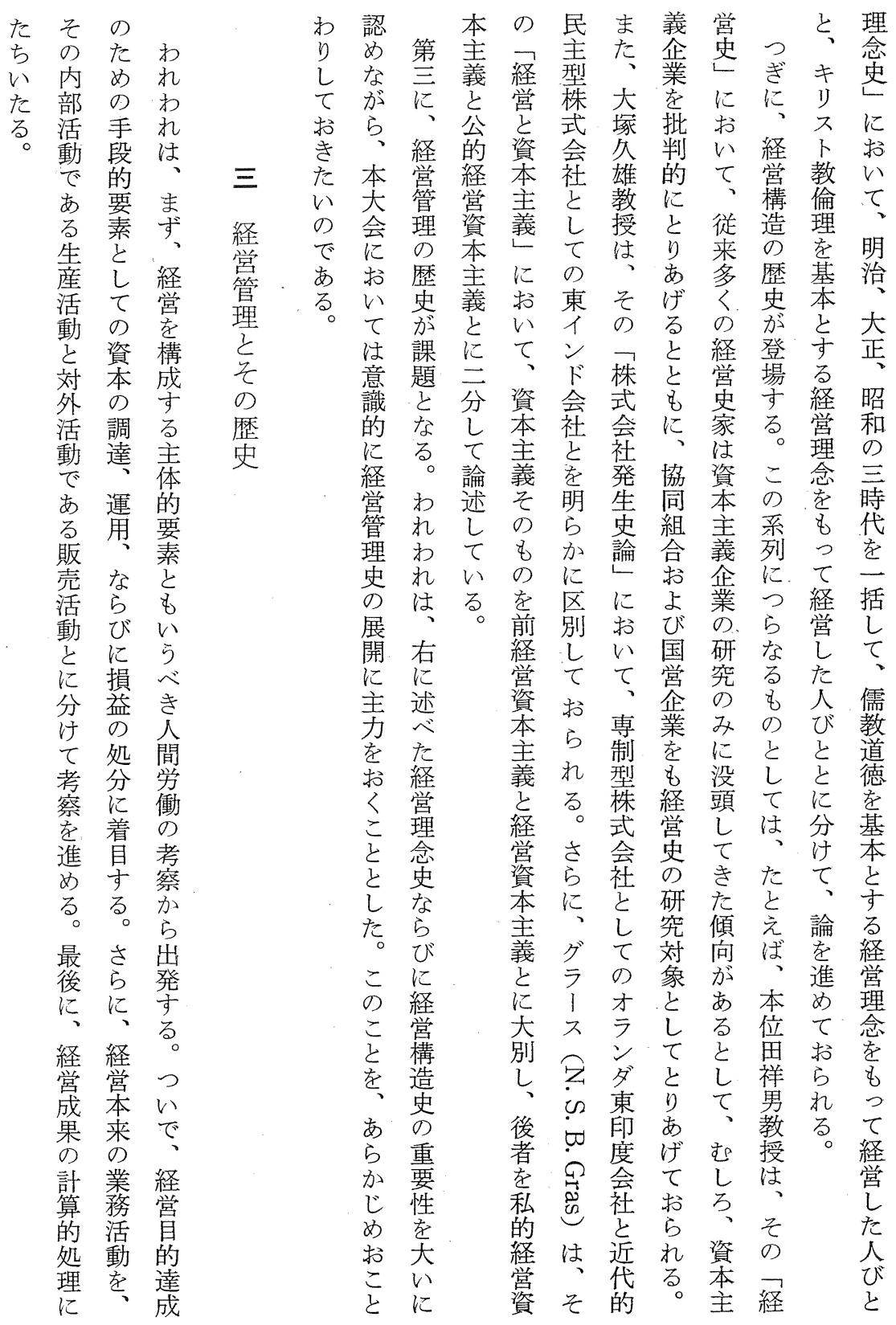


第 9 巻 第 1 号

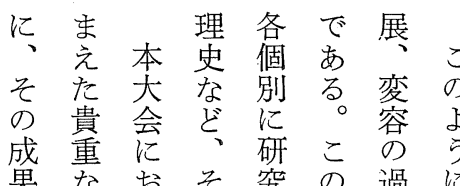

果なおそ究の過に

に研い机対総程

大究てぞ象括を労

い報は年的歴働

に告、独しな史加

期㤎こ自て見的ら

待、れ の見地に出

す 順 ら研定にあ 発

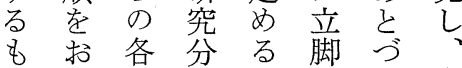

の口分野と汀資

でて野がきるよ本

あくに開、経 ら

るり尔拓气賞余生

ひたさこ管企産

げてる労史る販

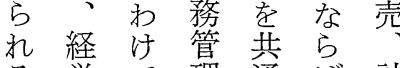

る。営で理通ば計

わ的方基々処

た思。財盤こ理

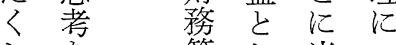

し管し当い

は究理て然た

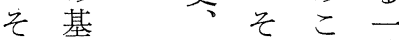

の礎生こ立連

ひに産になの

とお管 内 が 経

き理包ら営

ひ史さ経機

とし営能

つか販て管を

に导 壳理 対

深、管る史象

い適理そ吕と

関切更杂杂主

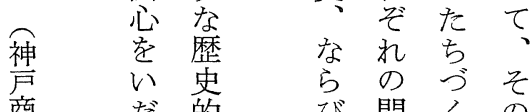

商科的閣くの

梨文事䚺題 5 生

を学整域る 


\title{
BUSINESS ADMINISTRATION AND BUSINESS HISTORY
}

\author{
Shinzo Kurita \\ Kõbe University of Commerce
}

Six articles in this issue are papers read at the common-topics session of the ninth annual meeting of the Business History Society of Japan, held at Kōbe University of Commerce on November 10 and 11, 1973.

In the opening address, Kurita pointed out that the aim of this symposium lay in analysing the interrelationship between "Business Administration and Business History". There are three approaches in studying business history : history of the business thought; history of the business structures; history of the business management. Kurita emphasized the possibility of multiple approaches, suggesting five genres of the histoty of business management_labour management; financial management; production management; marketing management; and accounting management.

The second speaker, Professor Seiji Fujitsu (Hitotsubashi University), explained, to the minutest detail, the development of the standardprofit concept at Onoda Cement Manufacturing Company, which was one of the pioneering modern enterprises in Meiji-Japan. He pointed out that Onoda Cement Manufacturing Company was the earliest enterprise tackling with the problem of depreciation-expense. (Commentator; Professor Jiro Ono, Kōbe University).

Professor Hiroshi Noguchi (Keio University) tried to trace the historical characteristics of the labour management in Japan. He concretely reported about "the Japan-Type-Labour-Management", which had a couple of unique marks - the system of employment for life; the institution of generous welfare; and the special personnel relationship based on the business community. (Commentator: Professor Hiroshi Hazama, Tokyo University of Education).

Professor Hiroshi Tachibana (Osaka Municipal University) insisted 
the importance of the historical approach in the study of production control, reviewing the development of capitalistic-factory-production during the recent two centuries, together with the contemporary thoughts and systems of production control. He also analyzed the current structure and function of the production control in detail, from the historical view point. (Commentator: Professor Kisoo Tasugi, KyotoGakuen University).

Professor Kōichi Shimokawa (Hōsei University) reported on the origin and growth of the marketing control in the United States during the latter half of the 19 th century. He found the origin of the marketing as a means of control in the early development of salesmen control, promoted in some new consumers' goods industries, such as sewing-machine, reaper, meat-packing and cigarette, to which neither established marketing organization nor sales agency could afford enough sales facilities. (Commentator: Professor Moriaki Tsuchiya, Tokyo University).

Professor Eiichiro Ogura (Shiga University) gave the audience a corroborative business-history-research of the accounting management. Analyzing the cases of House of Nakai and Muranishi together with Izumo-account, he put emphasis on the existences of the managerial-accounting and the cost-accounting in Tokugawa-Japan. (Commentator: Professor Osao Kojima, Kwansei Gakuin University).

Co-chairmen of this symposium were Professor Yasuzō Horie (Kyōto Sangyō University) and Professor Keiichiro Nakagawa (Tokyo University). 